\title{
Z DWORU ZIEMIAŃSKIEGO NA UNIWERSYTECKĄ KATEDRE PRZYCZYNEK DO GENEZY INTELIGENCJI POLSKIEJ
}

\begin{abstract}
Streszczenie. Ziemiaństwo i inteligencja to dwie warstwy społeczeństwa polskiego, które wzajemnie się uzupełniały i odgrywały ważną rolę w utrzymaniu polskości w dobie zaborów, oraz poważnie przyczyniły się do odzyskania niepodległości w 1918 r. Wykształcony ziemianin, czy też inteligent pochodzenia ziemiańskiego, jak trudno było nieraz określić przynależność do konkretnej warstwy społecznej. Publicyści po powstaniu styczniowym pisali wręcz o ziemiaństwie jako ,inteligencji wiejskiej”, która miała odegrać istotną rolę w modernizacji wsi polskiej. W świetle dotychczasowych ustaleń historiografii wynika, iż rzeczywiście środowisko ziemiańskie stało się jedną z głównych grup rekrutacji polskiej inteligencji w drugiej połowie XIX i pierwszej połowie XX w.

Analiza źródeł różnej proweniencji wskazuje, iż jedną z najważniejszych inteligenckich grup zawodowych, do której trafiali najpierw synowie, a następnie i córki z rodzin ziemiańskich, byli naukowcy. Zasadniczym problemem badawczym jest próba charakterystyki ludzi nauki, którzy porzucali dwory i decydowali się na karierę w uczelniach wpierw Krakowa, Lwowa i Warszawy, a po odzyskaniu niepodległości także Poznania, Wilna i Lublina. Zagadnienie to omówione zostanie zarówno w szerszym kontekście losów zbiorowych, jak również wybranych indywidualnych biografii uczonych polskich o ziemiańskim rodowodzie. Ważnym kryterium wyboru będzie ich jednoczesne zaangażowanie w różnych przedsięwzięciach o charakterze politycznym i społecznym.
\end{abstract}

Słowa kluczowe: ziemiaństwo, katedra uniwersytecka, inteligencja.

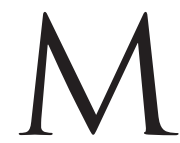

ojej refleksji poddani zostaną przedstawiciele środowiska ziemiańskiego, którzy zdecydowali się na realizację kariery naukowej na wyższych uczelniach w XIX-XX w. Pomijam tych ziemian, którzy realizowali nawet $z$ dużym powodzeniem swoje hobby i pasje naukowe, np. historyczne, archeologiczne czy etnograficzne poza instytucjami naukowymi. Podjęte przeze mnie zagadnienie omówione zostanie zarówno w szerszym kontekście losów zbiorowych, jak również wybranych indywidualnych biografii uczonych polskich o ziemiańskim rodowodzie. Skupiam się przede wszystkim na przed-

\footnotetext{
* Uniwersytet Łódzki, Wydział Filozoficzno-Historyczny, Katedra Historii Polski XIX w., email: jaroslawkita@poczta.onet.pl.
} 
stawicielach środowiska ziemiańskiego zamieszkujących dawne tereny Rzeczypospolitej, które w dobie zaborów znalazły się pod panowaniem rosyjskim. Podkreślam, iż nie chodzi mi tutaj o ludzi pochodzenia szlacheckiego, najczęściej pozbawionych dóbr ziemskich, których jakże wielu znalazło się w warstwie inteligencji, poszukując źródeł dla dalszego bytowania. W kręgu moich rozważań znajdują się wyłącznie potomkowie osób posiadających majątki ziemskie, czyli rzeczywiste środowisko ziemiańskie.

\section{Ziemiaństwo a inteligencja}

Ziemiaństwo i inteligencja to dwie warstwy społeczeństwa polskiego w XIX i pierwszej połowie XX w., które wzajemnie uzupełniały się i odgrywały najważniejszą rolę $\mathrm{w}$ utrzymaniu polskości $\mathrm{w}$ dobie zaborów, a także poważnie przyczyniły się do odzyskania niepodległości w 1918 r. Wykształcony ziemianin, czy może już inteligent pochodzenia ziemiańskiego, jakże trudno było nieraz określić jednoznacznie przynależność do konkretnej warstwy społecznej. Jeśli przyjmiemy definicję, że w interesującym mnie okresie inteligencja to warstwa społeczna składająca się z ludzi wykształconych i żyjących z pracy umysłu, a więc obejmująca takie profesje jak lekarze, prawnicy, nauczyciele, literaci i artyści, technicy i inżynierowie, ale również urzędnicy to, szczególnie w czasach Księstwa Warszawskiego i Królestwa Polskiego w jego konstytucyjnym okresie, rzeczywistość jeszcze bardziej będzie zagmatwana. Pomiędzy 1807 a $1830 \mathrm{r}$. wiele stanowisk w aparacie władzy i strukturach administracyjnych zajmowali ludzie pobierający za wykonywane czynności wcale niemałe pobory, a jednocześnie posiadający lub dziedziczący majątki ziemskie. Także niejeden z wykonujących inne tzw. zawody inteligenckie posiadał jednocześnie majątek ziemski albo właścicielem dóbr był ojciec, po którym mógł dziedziczyć. Ta ostatnia konstatacja dotyczy także i późniejszego okresu naszych dziejów. W efekcie tego procesu można wskazać na zjawisko kulturowe, które można określić jako dwuśrodowiskowe życie części ziemiaństwa. Niejednokrotnie dziedzic piastujący urzędy pozostawiał rodzinę w odziedziczonych majątkach lub mająteczkach, które egzystowały dzięki dochodom lub zarobkom z umysłowej pracy najemnej. $Z$ drugiej strony ludzie pochodzenia szlacheckiego wykonując zawody inteligenckie zdobywali środki na zakup małego majątku ziemskiego, w którym osiedlali się pod koniec życia, wracając do środowiska ziemiańskiego (np. Henryk Lisicki spokrewniony z Mycielskimi). Można jeszcze dodać, iż część profesorów Uniwersytetu Jagiellońskiego posiadała niewielkie mająteczki ziemskie (dwór z parkiem i niewielkimi gruntami ornymi) położone w okolicach

${ }^{1}$ Szerzej zob.: Dzieje inteligencji polskiej do roku 1918 r., pod red. J. Jedlickiego, t. 1: M. Janowski, Narodziny inteligencji 1750-1831, Warszawa 2008; R. Czepulis-Rastenis, „Klassa umysłowa”. Inteligencja polska Królestwa Polskiego 1832-1862, Warszawa 1973. 
Krakowa. Zdaniem Andrzeja Szwarca, szczególnie na gruncie galicyjskim, miały miejsce ścisłe związki inteligencji z ziemiaństwem, a łącznikiem były takie autorytety jak np. Stanisław hrabia Tarnowski, profesor i rektor Uniwersytetu Jagiellońskiego ${ }^{2}$. W XIX w., a także w okresie Drugiej Rzeczypospolitej aż do II wojny światowej, posiadanie siedziby na wsi było w dobrym tonie wśród zamożnych przedsiębiorców i przedstawicieli zawodów inteligenckich - adwokatów, lekarzy, architektów, literatów.

Publicyści po powstaniu styczniowym, szczególnie ci wywodzący się ze środowiska pozytywistycznego, pisali wręcz o ziemiaństwie jako ,inteligencji wiejskiej”, która miała odegrać istotną rolę w modernizacji gospodarczej i społecznej wsi polskiej ${ }^{3}$. W świetle dotychczasowych ustaleń historiografii rzeczywiście środowisko ziemiańskie stało się jedną z ważnych grup rekrutacji polskiej inteligencji w drugiej połowie XIX w., a szczególnie w latach Drugiej Rzeczypospolitej $^{4}$. Ziemiaństwo zaczęło wówczas utożsamiać się z inteligencją, co świadczy o istotnej zmianie kulturowej. W krótkim okresie do wybuchu II wojny światowej inteligencja stała się „,zmodernizowanym” następcą ziemiaństwa. Warstwa inteligencka była więc kategorią pojemną, pośredniczącą między różnymi warstwami społecznymi, grupami etnicznymi, środowiskami zawodowymi. Jej członkowie uważali się za elitę i za taką uznawali ją inni. Była to jednocześnie elita służebna wobec narodu, odpowiedzialna m.in. za przechowywanie tradycji narodowych.

Analiza źródeł różnej proweniencji wskazuje, iż jedną z najważniejszych inteligenckich grup zawodowych, do której w XIX stuleciu trafiali najpierw synowie, a później także i córki z rodzin ziemiańskich, byli naukowcy. Zasadniczym problemem badawczym w tym tekście jest próba charakterystyki ludzi nauki, którzy „porzucali” dwory, rzadziej pałace, decydując się na karierę naukową w uczelniach najpierw Krakowa, Lwowa i Warszawy, a po odzyskaniu niepodległości w 1918 r. także Poznania, Wilna i Lublina. Również po 1945 r., w nowych realiach powojennej Polski Ludowej, wśród naukowców istniejących już uczelni, jak i tych tworzonych od podstaw, pojawili się przedstawiciele środowiska ziemiańskiego. Należy podkreślić, iż wówczas już byłej warstwy ziemiańskiej, gdyż zniknęła ona ze struktury społecznej nowego socjalistycznego społeczeń-

${ }^{2}$ Stanisław hrabia Tarnowski, herbu Leliwa (1837-1917) - profesor i rektor Uniwersytetu Jagiellońskiego, historyk literatury i publicysta, jeden z przywódców stańczyków - konserwatystów galicyjskich, prezes Akademii Umiejętności w Krakowie.

3 J. Kita, Идеальный польский помещик в представлении варшавских позитивистов, [w:] Модернизация в центральной и восточной Европе. Идеи, програмы, реализация, от. ред. Г.Ф. Матвеев, Мосгорархив, Мосkва 2000, с. 25-34; idem, Ziemian Królestwa Polskiego obraz własny, „Studia z Historii Społeczno-Gospodarczej XIX i XX wieku” 2003, t. 1, pod red. W. Pusia, s. $134-146$.

${ }^{4}$ Zob. J. Żarnowski, Inteligencja, [w:] W. Mędrzecki, Sz. Rudnicki, J. Żarnowski, Społeczeństwo polskie w XX wieku, Warszawa 2003, s. 74-78; idem, O inteligencji polskiej lat międzywojennych, Warszawa 1965, s. 8. 
stwa przede wszystkim w wyniku reformy rolnej PKWN z 1944 r., pozbawiającej właścicieli ziemskich praw do majątków ziemskich. Ponadto w warunkach komunistycznej Polski starano się wytworzyć inną inteligencję, a mianowicie jak ją zaczęto określać - inteligencję pracującą, czyli biurokrację partyjno-państwową (,partokrację”) i rzesze najemnych pracowników umysłowych. Ta grupa społeczna, według Bogusława Doparta:

nie miała nic wspólnego ze znanym nam z historii inteligenckim zespołem wartości. W polskich warunkach byt on nierozerwalna synteza tradycji romantycznej i pozytywistycznej. A więc ojczyzna, ale i cywilizacja. Wykształcenie, ale i praca. Racjonalność, ale i idealizm moralny. Aktywność twórcza, ale i stużba społeczna 5 .

Środowisko ziemiańskie nie było jednolite nie tylko pod względem majątkowym, ale również stosunku do kultury i nauki. Szereg istniejących różnego typu opracowań wskazuje, iż przynależność do grupy o konkretnym statusie majątkowym nie musiała determinować skali i poziomu aktywności kulturalnej i edukacyjnej. Zarówno wśród ziemian dysponujących tysiącami mórg, jak i pomiędzy właścicielami niewielkich mająteczków ziemskich, znajdowali się ludzie obdarzeni szerokimi horyzontami intelektualnymi, którzy do edukacji i nauki przykładali ogromną wagę. Reprezentowali model rodziny, w której celem nadrzędnym było dotrzymanie kroku zachodzącym przemianom cywilizacyjnym i oświatowym. Jednym z podstawowych zadań stawało się wykształcenie dorastających dzieci w takim kierunku, który pozwalałby im na pełnienie ról inteligenckich, w jakimś stopniu niezależnie od posiadania ziemi. $Z$ drugiej strony, niezależnie od wielkości majątku, byli tacy, których charakteryzowały ciasne poglądy i obojętność na sprawy kultury i nauki, a nawet niekiedy wręcz pogarda dla ludzi parających się tymi płaszczyznami aktywności ludzkiej ${ }^{6}$.

Jeszcze w pierwszych dekadach XIX w. zostanie nauczycielem, nawet w szkole wyższej, przez przedstawiciela środowiska szlachecko-ziemiańskiego bywało postrzegane jako forma deklasacji. Doświadczył tego choćby Fryderyk Skarbek, który wspominał, iż jego przyszły teść na wieść, iż ma „przyjąć posadę bakalarską, [...] zaczął namawiać córkę swą, aby mnie porzuciła" . A przecież to bakalarstwo F. Skarbka miało być realizowane na Królewskim Uniwersytecie Warszawskim na Wydziale Prawa i Administracji. Należy przy tym dodać, iż ród teściów (Gzowskich) nie zaliczał się do elity ziemiańskiej. Ostatecznie w 1818 r. F. Skarbek pojął za żonę Praksedę Gzowską i został zastępcą profesora

\footnotetext{
${ }^{5}$ Podaję za: E. Polak-Pałkiewicz, Czy inteligencja istnieje?, „Niedziela” 2006, nr 29, s. 18.

${ }^{6}$ Zob. P.Sz. Łoś, Szkice do portretu ziemian polskich XX wieku, Warszawa 2005, passim. Taką rodziną byli np. Szeptyccy, ibidem, s. 381-382.

${ }^{7}$ F. Skarbek, Pamiętniki Fryderyka hrabiego Skarbka, oprac. P. Mysłakowski, Warszawa 2009, s. 168.
} 
ekonomii politycznej na UW. W 1820 r., po wcześniejszym uzyskaniu stopnia doktora na Uniwersytecie w Krakowie (1819) mianowano go profesorem nauk administracyjnych warszawskiej uczelni ${ }^{8}$. „Profesor hrabia Skarbek”, jak zanotował w pamiętniku, ,wbrew dawnych przesądów, jako obywatel ziemski z tytułem rodowym, nie wahałem się poświęcić zawodowi nauczycielskiemu". Z jego zapisów można wywnioskować, że posada profesora była dla niego atrakcyjna również ze względów finansowych, a ponadto jak okazało się niebawem dała mu możliwości objęcia stanowiska rządowego9.

Przechodzenie do pracy zawodowej, wymagającej stałej obecności w miejscu zatrudnienia, a dodatkowo jeszcze miejskiej, w połowie XIX w. odczuwano nadal jako swoistą deklasację. Sytuacja zmieniała się dopiero w drugiej połowie XIX w. Konsekwencje klęski powstania styczniowego i uwłaszczenia chłopów, działalność pozytywistów warszawskich i szybkie przemiany cywilizacyjne wywołane postępującą europeizacją ziem polskich skłaniały do zmiany spojrzenia na tzw. zawody inteligenckie. Przystosowując swoje wzory i normy obyczajowe do nowych sytuacji społeczno-zawodowych role inteligenckie stawały się dla wykształconych ziemian, szczególnie tych borykających się z problemami gospodarczymi, bardziej atrakcyjne niż prowadzenie własnych majątków. Chociaż nadal w niejednej rodzinie ziemiańskiej, jak podkreślał Michał Żółtowski, wybór innego niż rolniczy zawód nie był dobrze widziany. Jeszcze przed $1914 \mathrm{r}$. uważano, że np. zajęcie się pracą naukową jest ,,poniżej godności ziemianina ze szlacheckiej rodziny"10.

Po odzyskaniu niepodległości przez Rzeczpospolitą sytuacja zmieniła się. Ziemiaństwo szukało dla siebie miejsca w nowej rzeczywistości, która otwierała szereg różnych możliwości. Kraj potrzebował ludzi wykształconych, część młodzieży ziemiańskiej pragnęła podjąć się innych zadań, niekoniecznie związanych z rolnictwem. Zmniejszała się niechęć do zajęć pozarolniczych, a wzrastała świadomość, iż nie wszyscy mogą zostać na wsi ${ }^{11}$. Dla młodzieży z dworów szczególnie atrakcyjne stały się profesje naukowe i artystyczne, wojsko, dyplomacja, przemysł $\mathrm{i}$ instytucje rządowe. W XX w. studia były już niemal wpisane w status młodych ziemian, co nie znaczy, że wszyscy je kończyli. Szereg ciekawych refleksji w tym względzie dostarcza lektura kolejnych tomów serii Ziemianie polscy $X X$ wieku ${ }^{12}$.

8 J. Bieliński, Królewski Uniwersytet Warszawski, t. 2, Warszawa 1911, s. 440-441; M. Mycielski, Uniwersytet Królewski 1816-1831, [w:] Dzieje Uniwersytetu Warszawskiego 1816-1915, red. T. Kizwalter, Warszawa 2016, s. 157-159.

9 F. Skarbek, op. cit., s. 168-171.

${ }^{10}$ Relacja M. Żółtowskiego, rkp., Laski, 1 X 2000 r. Podaję za: P.Sz. Łoś, op. cit., s. 229.

11 Zob. szerzej: S. Rudnicki, Ziemiaństwo polskie w XX wieku, Warszawa 1996.

${ }_{12}$ Ziemianie polscy XX wieku. Słownik biograficzny, t. 1-11, red. J. Leskiewiczowa, T. Epsztein, Warszawa 1992-2016. 


\section{Warunki rozwoju nauki polskiej}

Przyjrzyjmy się warunkom i możliwościom, które determinowały rozwój polskiej nauki, a tym samym dawały szansę również ludziom ze środowiska ziemiańskiego na karierę naukową i uzyskanie profesury na uczelni. Polityka władz zaborczych szczególnie niekorzystnie odbijała się na funkcjonowaniu uczelni i nauki polskiej. W okresie braku państwowości, w zaborze pruskim nie działała ani jedna polska szkoła wyższa. Z drugiej strony, w Wielkim Księstwie Poznańskim ziemiaństwo najbardziej nowocześnie podchodziło do życia i szybko postępujących zmian cywilizacyjnych, patrząc przez pryzmat całego środowiska ziemiańskiego $\mathrm{w}$ skali wszystkich części podzielonych ziem polskich. Po 1871 r. szereg rodzin ziemiańskich, najczęściej posiadających duży majątek, decydowało się na wysłanie synów na studia. Jak wykazują badania Witolda Molika, wyjeżdżali oni przede wszystkim do uczelni niemieckich, gdzie nie było jednak dla nich przychylnej atmosfery, aby rozpocząc karierę naukową. Dla przykładu w jednym z najczęściej wybieranych przez Polaków uniwersytecie w Heidelbergu wśród immatrykulowanych studentów w latach 1871-1914 synowie ziemiańscy stanowili aż 46,4\%. Równie wysoki odsetek stanowili synowie ziemian w uniwersytecie w Monachium. Nawet w najbardziej ,plebejskim” z ówczesnych niemieckich uniwersytetów we Wrocławiu stanowili oni blisko $30 \%$ wśród immatrykulowanych Polaków ${ }^{13}$. Trudno jednak szukać wśród kadry profesorskiej tych uczelni nazwisk polskich ziemian.

Z kolei w zaborze rosyjskim, poza krótkim, chociaż niezmiernie istotnym okresem funkcjonowania Szkoły Głównej Warszawskiej (1862-1869), w 50-leciu po powstaniu styczniowym istniał Cesarski Uniwersytet Warszawski, w którym cały czas utrzymywano zasady nie zawsze korzystne dla studiujących tu Polaków. Tytułem przykładu, absolwenci tej uczelni chcący dalej pracować naukowo nie mogli zostać docentami tzw. prywatnymi (habilitacja), co było warunkiem objęcia katedry profesorskiej. Było to konsekwencją rusyfikacyjnej polityki władz, której celem było ograniczenie liczby polskiej kadry. Profesorów Rosjan starano się ściągać do Warszawy zaraz po likwidacji Szkoły Głównej i zastąpieniu jej Cesarskim Uniwersytetem Warszawskim. Atmosfera panująca na tej uczelni nie sprzyjała więc Polakom, a w tym synom ziemiańskim, do podjęcia wówczas akademickiej kariery naukowej. Jako ilustracja tej tezy niech posłużą liczby. W latach 1870-1900 Polacy stanowili ponad połowę studiujących na uniwersytecie, ale tylko 21 uzyskało stopień magistra (odpowiednik doktora na uczelniach zachodnich), a 9 uzyskało doktorat (nie licząc nauk medycznych, w których przyznano 60 osobom stopień doktora, ale był on jedynym istniejącym w tej dyscyplinie). W 1870 r. liczba Polaków - pracowników naukowych Uniwersytetu wynosiła

13 W. Molik, Polskie peregrynacje uniwersyteckie do Niemiec 1871-1914, Poznań 1989, s. $73-74$. 
36, ale w 1895 r. już tylko $9^{14}$. Młodzież ziemiańska z Królestwa Polskiego, a przede wszystkim z guberni kresowych, nierzadko wyjeżdżała na uczelnie istniejące w miastach Cesarstwa Rosyjskiego oraz do krajów Europy Zachodniej (głównie niemieckich i francuskich) ${ }^{15}$. Ale jak wskazywałem wcześniej tam możliwości zrobienia kariery naukowej, a jeszcze bardziej uzyskanie katedry profesorskiej były zdecydowanie ograniczone ${ }^{16}$. Młodzi ludzie po ukończeniu jednej uczelni wyruszali nieraz na dalsze peregrynacje naukowe do ośrodków słynących z dokonań w danej dziedzinie. Uzyskane bardzo dobre wykształcenie na tych uczelniach pozwoliło, już jednak w czasach Drugiej Rzeczypospolitej, na podjęcie pracy naukowej w polskich uczelniach ${ }^{17}$.

Zdecydowanie najkorzystniejsze warunki dla zdobywania kolejnych stopni naukowych i objęcia katedr profesorskich mieli Polacy w Galicji w związku z repolonizacją tamtejszych uczelni w Krakowie i Lwowie w latach 70. XIX w. Rozważania te dotyczą jedynie mężczyzn, gdyż do 1894 r. bramy polskich uniwersytetów były zamknięte dla kobiet, jednak pionierki kształciły się już za granicą. Wśród nich trudno byłoby jednak szukać kobiet pochodzących ze środowiska ziemiańskiego, chociaż ze szlacheckimi korzeniami już tak. Dopiero początek XX w. przyniósł zmiany i pierwsze córki ziemiańskie podejmowały studia na kursach dla kobiet prowadzonych na uczelniach. Jednak droga do poważniejszej kariery naukowej była dla nich do końca okresu zaborów zamknięta. Sytuacja ta ulegnie zmianie dopiero w czasach Drugiej Rzeczypospolitej, chociaż i wówczas kobiety nie miały równych szans na realizację naukowych aspiracji ${ }^{18}$.

${ }^{14}$ Szerzej zob.: I. Ihnatowicz, Uniwersytet Warszawski w latach 1869-1899, [w:] Dzieje Uniwersytetu Warszawskiego 1807-1915, red. S. Kieniewicz, Warszawa 1981, s. 389-393, 402, 421; H. Kiepurska, Uniwersytet Warszawski w latach 1899-1915, [w:] ibidem, s. 480-483, 531-532; J. Schiller, Universitas rossica. Koncepcja rosyjskiego uniwersytetu 1863-1917, Warszawa 2008, s. 262-269.

${ }^{15}$ T. Epsztein, Edukacja dzieci i młodzieży w polskich rodzinach ziemiańskich na Wołyniu, Podolu i Ukrainie w II połowie XIX wieku, Warszawa 1998, s. 83 i n.; W. Molik, op. cit., s. 75.

${ }^{16}$ Jednym z wyjątków był Jan Sleszyński (Śleszyński) (1854-1931). Urodził się w Łysiance w gub. kijowskiej. Był synem ziemianina Władysława Doliwa-Śleszyńskiego. Po ukończeniu nauki na Uniwersytecie w Odessie i studiach uzupełniających w Berlinie, w 1883 r. został zatrudniony na Uniwersytecie w Odessie w charakterze docenta prywatnego. W 1898 r. został mianowany na profesora zwyczajnego. Zob. M. Przeniosło, Matematycy polscy w dwudziestoleciu międzywojennym. Studium historyczne, Kielce 2011, s. 405.

${ }^{17}$ M. Przeniosło (ibidem, s. 15-16) podaje, że niemal wszyscy profesorowie matematyki z okresu Drugiej Rzeczypospolitej w ten sposób poznawali ówczesny świat naukowy, dokształcając się na najlepszych uniwersytetach francuskich i niemieckich. Por. U. Perkowska, Ksztattowanie się zespotu naukowego w Uniwersytecie Jagiellońskim (1860-1920), Wrocław 1975, s. 89.

${ }^{18}$ U. Perkowska, Kariery naukowe kobiet na Uniwersytecie Jagiellońskim w latach 1904-1939, [w:] Kobieta i kultura. Kobiety wśród twórców kultury intelektualnej i artystycznej w dobie rozbiorów i w niepodległym państwie, pod red. A. Żarnowskiej i A. Szwarca, Warszawa 1996, s. 148-149; eadem, Studentki Uniwersytetu Jagiellońskiego w latach 1894-1939. W stulecie immatrykulacji pierwszych studentek, Kraków 1994, s. 36-37; J. Halbersztadt, Kobiety w murach Uniwersytetu 
Informacje o pochodzeniu społecznym profesorów polskich uczelni w okresie zaborów są niestety dosyć ubogie, ale dostarczają jednak pewnych elementów do wnioskowania. Najczęściej podawano pochodzenie szlacheckie i trudno wówczas bezpośrednio stwierdzić, która z tych osób rzeczywiście urodziła się w rodzinie ziemiańskiej. Tylko w niektórych przypadkach można posiłkować się informacjami zawartymi w źródłach różnej proweniencji, np. pamiętnikach, nekrologach, spisach ziemian i innych podobnych źródłach. W przypadku Szkoły Głównej i Cesarskiego Uniwersytetu Warszawskiego akta tych uczelni są bardzo zdekompletowane i interesujące mnie informacje w tej sprawie są niezmiernie rzadkie ${ }^{19}$.

Generalnie wśród profesorów Cesarskiego Uniwersytetu Warszawskiego po 1869 r. przeważali profesorowie pochodzenia szlacheckiego. W 1874 r. połowa z Polaków - kadry dydaktycznej (26 na 52) podawała pozycję społeczną ojca - szlachcic ${ }^{20}$. Jednak w grupie profesorów wskaźnik ten był jeszcze wyższy. Udało się ustalić, iż spora grupa $\mathrm{z}$ tych profesorów urodziła się $\mathrm{w}$ rodzinach ziemiańskich, jednak najczęściej w momencie kiedy obejmowali katedry, już niejednokrotnie zubożałych lub nie będących właścicielami majątku ziemskiego. Ze względu na brak pełnych danych statystycznych, a ponadto różniące się niejednokrotnie w przekazie źródła różnej proweniencji, nie będę podejmował próby dokładnych wyliczeń procentowych. Ziemiańskie korzenie spośród kadry profesorskiej tej uczelni mieli m.in.: doktor medycyny i pionier chemii lekarskiej Herman Bolesław Fudakowski (25 października 1834 - 10 listopada 1878), chirurg Julian Kosiński (16 listopada 1833 - 24 marca 1914); prawnik Antoni Białecki (11 czerwca 1836 - 15 listopada 1912), prawnik Antoni Okolski (Okólski) (1 maja 1838 - 30 października 1897), matematyk Tytus Babczyński (4 stycznia 1830 - 19 czerwca 1910), prawnik Władysław Holewiński (19 września 1834 - 8 października 1919), ornitolog Władysław Taczanowski (1 marca 1819 - 17 stycznia 1890) i jeszcze kilku innych, co do których nie udało się jednoznacznie rozstrzygnąć czy wywodzili się z ziemiaństwa, czy też mieli jedynie szlacheckich przodków. Wszyscy oni urodzili się zaraz po klęsce powstania listopadowego, a jedynym wyjątkiem był najstarszy w tym gronie Władysław Taczanowski.

Warszawskiego 1915-1939, [w:] Kobieta i kultura. Kobiety..., s. 111-112; M. Kondracka, Kobiety na uniwersytetach, [w:] Równe prawa i nierówne szanse. Kobiety w Polsce międzywojennej, pod red. A. Żarnowskiej i A. Szwarca, Warszawa 2000, s. 271-273; D. Mazurczak, Kariery akademickie kobiet w Polsce międzywojennej - Uniwersytet Poznański, [w:] Kobieta i kultura. Kobiety..., s. 131-132; J. Kolbuszewska, Kobiety w nauce - akademicki awans polskich historyczek wczoraj i dziś, „Sensus Historiae” 2015, t. 19, nr 2, s. 109-115.

19 Por. A. Cywińska, L. Nalewajska, Mistrzowie i przewodnicy. Profesorowie Warszawskiej Szkoły Głównej (1862-1869). Warszawa 2012.

${ }^{20}$ I. Ihnatowicz, op. cit., s. 437. 
Herman Bolesław Fudakowski herbu Dołęga urodził się na Ukrainie w majątku Śwityńce (Śwityńka). Był synem zamożnego ziemianina Ignacego Fudakowskiego (1808-1891) i Julii ze Zbyszewskich herbu Topór (1804-1867). Rodzice posiadali jeszcze majątek Skoromoszki. Później jego ojciec nabył dobra Klesztów, Dryszczów, Roztoki i Żmudź w pow. chełmskim. Większość majątków została jednak skonfiskowana za udział ojca i najstarszego brata Zygmunta w powstaniu styczniowym. Stąd też pochodząc z licznej rodziny musiał znaleźć zatrudnienie zapewniające mu środki do życia. Prof. Herman B. Fudakowski, absolwent Uniwersytetu w Dorpacie (tutaj uzyskał stopień doktora medycyny w 1859 r.), następnie docent i profesor Szkoły Głównej, a od 1869 r. Cesarskiego Uniwersytetu Warszawskiego, zmarł niestety młodo zaledwie w wieku 44 lat $^{21}$. W obszernym artykule wspomnieniowym zamieszczonym na łamach „Kłosów” w 1878 r. dr Hipolit Skimborowicz podkreślał wielkie zasługi naukowe zmarłego, pomimo młodego wieku, dostrzegane przez środowisko pisząc:

Towarzystwa naukowe zagraniczne (np. niemieckie), jak również i krajowe, obdarzaty uczonego Męża tytułami członków swoich, bądź czynnych, bądź korrespondentów ${ }^{22}$.

Julian Kosiński herbu Rawicz, absolwent medycyny na Akademii Wojskowo-Lekarskiej w Petersburgu urodził się w Iwoniszkach w dawnym pow. rosieńskim. Uznawany jest za pioniera $\mathrm{w}$ dziedzinie antyseptyki oraz aseptyki na ziemiach polskich $^{23}$. Od 1869 r. związany był zawodowo ze Szkołą Główną, a następnie Cesarskim Uniwersytetem Warszawskim. W 1899 r. za swoje zasługi otrzymał tytuł zasłużonego profesora $\mathrm{UW}^{24}$. Jego żoną była Maria Teresa, córka generała Aleksandra Hauke, prezesa Warszawskich Teatrów Rządowych. Na początku XX w. wspólnie z dr Adamem Przyborowskim nabył część majątku Brzegi pod Otwockiem, z zamiarem zorganizowania tam sanatorium dziecięcego. Pomimo zatwierdzenia projektu przez władze rosyjskie do jego realizacji nie doszło ${ }^{25}$.

Antoni Władysław Emilian Białecki, rocznik 1836, był synem ziemianina Kazimierza Białeckiego i Domicelli z Bartoszewskich. Studia prawnicze odbywał na Uniwersytecie Jagiellońskim i Uniwersytecie w Heidelbergu. Od 1862 r.

${ }^{21}$ M. Manteufflowa, Fudakowski Herman Bolestaw (1834-1878), [w:] Polski Stownik Biograficzny [dalej: PSB], t. 7, Kraków-Wrocław 1948-1958, s. 177; I. Broszkowska, Fudakowscy herbu Dołęga. Gałąz uherska, „Wiadomości Ziemiańskie” 2006, nr 26, s. 36-38.

22 „Kłosy” 1878, nr 702, s. 375.

${ }^{23}$ A. Kierzek, Julian Kosiński (1833-1914) - chirurg szczególnie zastużony dla rozwoju otorynolaryngologii. Jego dokonania w leczeniu chorób krtani, „Otolaryngologia Polska” 2008, nr 2, s. 216-222; idem, Julian Kosiński (1833-1914) - chirurg szczególnie zastużony dla rozwoju otorynolaryngologii. Jego dokonania w leczeniu chorób uszu, nosa, gardła i pogranicza, „Otolaryngologia Polska" 2008, nr 2, s. 223-230.

${ }^{24}$ S. Sokół, Kosiński Julian (1833-1914), [w:] PSB, t. 14, Kraków-Wrocław 1968-1969, s. $216-218$.

${ }^{25}$ „Zdrowie” 1902, R. 18, z. 5, s. 409; „Zdrowie” 1903, R. 19, z. 4, s. 300-310. 
zatrudniony w Szkole Głównej, gdzie otrzymał tytuł profesora zwyczajnego. W 1869 r. pracował nad ustawą o przekształceniu likwidowanej uczelni założonej z inicjatywy Aleksandra Wielopolskiego w Cesarski Uniwersytet Warszawski. Do 1887 r. w tej uczelni kierował Katedrą Prawa Międzynarodowego ${ }^{26}$. Zmarł w Jordanowicach koło Grodziska Maz.

To samo pokolenie reprezentował Antoni Stanisław Zygmunt Okolski (Okólski) herbu Rawicz, wybitny prawnik, specjalista w zakresie prawa administracyjnego. Urodził się w Małachowicach w pow. łęczyckim. Jego ojciec Stanisław był właścicielem majątku ziemskiego o powierzchni 720 mórg $(1827 \text { r. })^{27}$. Antoni Okolski ukończył studia prawnicze w Petersburgu. Od 1865 r. wykładał w Szkole Głównej, a następnie był profesorem prawa państwowego w Cesarskim Uniwersytecie Warszawskim. Napisał szereg prac i podręczników, które służyły kolejnym pokoleniom słuchaczy prawa i administracji. Zmarł w Warszawie i został pochowany na Cmentarzu Powązkowskim ${ }^{28}$.

Matematyk Tytus Babczyński (rocznik 1830) był absolwentem Szkoły Sztuk Pięknych w Warszawie i Uniwersytetu w Petersburgu. Od 1862 r. związany zawodowo ze Szkołą Główną, a następnie Cesarskim Uniwersytetem Warszawskim $^{29}$. Po przejściu na emeryturę osiadł w swoim majątku Ulasek, w którym zmarł w 1910 r. ${ }^{30}$ Został pochowany na Cmentarzu Powązkowskim.

Prawnik Władysław Holewiński urodzony w 1834 r., ukończył uniwersytet w Petersburgu i podnosił swoje kwalifikacje zawodowe podczas pobytu na zachodzie Europy. Od 1862 r. zatrudniony w Szkole Głównej, kontynuował karierę naukową na Cesarskim Uniwersytecie Warszawskim do 1897 r., kiedy przeszedł na emeryturę ${ }^{31}$. Na łamach „Biesiady Literackiej” zamieszczono wówczas artykuł jemu poświęcony, w którym taką zamieszczono opinię:

Jako człowiek i obywatel, profesor Holewiński zawsze i wszędzie kierowat się najszlachetniejszymi zasadami. Nikomu, nigdzie i nigdy nie dworowat, nie szukat odznaczeń i rozgłosu. Szedt prosto i śmiało do celu, a celem tym, osia wszystkich jego myśli, jego przekonań, jego działań- była naukowa przeszłość i przyszłość kraju, uosobiona w młodem pokoleniu, które z zapałem kupiło się około swego przewodnika ${ }^{32}$.

${ }^{26}$ A. Bosiacki, Adam Białecki, [w:] Profesorowie Wydziału Prawa i Administracji Uniwersytetu Warszawskiego 1808-2008, praca zbiorowa pod red. G. Bałtruszajtys, Warszawa 2008; A. Moraczewski, Białecki Antoni Władysław Emiljan, [w:] PSB, t. 2, Kraków 1936, s. 5.

${ }^{27}$ Małachowice, [w:] Słownik geograficzny Królestwa Polskiego i innych krajów słowiańskich, t. 6, s. 26.

${ }^{28}$ W. Sobociński, Okolski Antoni Stanisław (1838-1897), [w:] PSB, t. 23, Wrocław 1978, s. $672-676$.

${ }^{29}$ A. Moraczewski, Babczyński Tytus (1830-1910), [w:] PSB, t. 1, Kraków 1935, s. 192.

30 „Kurier Warszawski”, nr 168, 20 VI 1910, s. 9; nr 169, 21 VI 1910, s. 4.

31 J. Litwin, Holewiński Władysław Eustachy (1834-1919), [w:] PSB, t. 9, Kraków-Wrocław 1960-1961, s. 582-583.

32 „Biesiada Literacka”, 1897, nr 11, s. 175. 
Władysław Taczanowski urodził się w rodzinnym majątku w Jabłonnie, w ówczesnym woj. lubelskim. Rodzinny dom sprzyjał pogłębianiu jego pasji przyrodniczych, którym się całkowicie poświęcił. W Szkole Głównej, a następnie w powstałym Uniwersytecie, jako kustosz, kierował przez wiele lat gabinetem zoologicznym. Najpewniej pochodzenie ziemiańskie umożliwiało mu kontakty z podróżnikami pochodzącymi z jego sfery (m.in. Aleksander i Konstanty Braniccy), którzy wspierali go w wyposażaniu gabinetu w okazy, albo zapraszali na wspólne zagraniczne wyprawy ${ }^{33}$. Stanisław Kramsztyk w artykule poświęconym W. Taczanowskiemu zamieszczonym na łamach „Kłosów” tak ocenił dorobek naukowca-ornitologa pochodzącego z dworu ziemiańskiego:

Zaszczytów Taczanowski nie szukat, dowody uznania wszakże zewsząd nań splywaty. Byt członkiem Akademii umiejętności w Krakowie, oraz wielu towarzystw ornitologicznych $i$ zoologicznych $w$ Rossyi, Francyi, w Niemczech i Anglii; $w$ inny też sposób naturaliści dawnym zwyczajem hołd mu składali, oznaczajac nazwiskiem jego liczne gatunki zwierzat, przez siebie odkrywane lub opisywane ${ }^{34}$.

W 1887 r. Uniwersytet Jagielloński nadał mu tytuł doktora honoris causa. Był autorem wielu prac naukowych poświęconych przede wszystkim ptakom i owadom ${ }^{35}$.

Wraz z wybuchem Wielkiej Wojny zmieniły się warunki funkcjonowania Cesarskiego Uniwersytetu Warszawskiego, który został przeniesiony do Rostowa nad Donem. Jesienią 1915 r. za zgodą generał-gubernatora warszawskiego Hansa von Beselera powołano do życia Uniwersytet Warszawski z językiem polskim jako wykładowym. Do faktycznie nowej uczelni, z własnym statutem, potrzebna była nowa kadra naukowa.

Jedną z najbardziej wyrazistych postaci ze środowiska ziemiańskiego w świecie nauki, która uzyskała wówczas zatrudnienie w Uniwersytecie Warszawskim był Alfons Parczewski herbu Nałęcz ${ }^{36}$. Urodził się 15 listopada 1849 r. w dużym majątku Wodzierady należącym do jego ojca Hipolita i matki Aleksandry z Bajerów. Ojciec poważnie zaangażowany w ruchu powstańczym 1863 r., zagrożony karą zesłania i konfiskaty majątku zdecydował o wysłaniu syna do szkoły średniej. Po ukończeniu gimnazjum w Kaliszu w 1865 r. A. Parczewski podjął studia

${ }^{33}$ A. Wrześniowski, Władysław Taczanowski wspomnienie pośmiertne, „Tygodnik Ilustrowany" 1890, nr 4, s. 53-54.

34 „Kłosy” 1890, nr 1282, s. 50.

35 A. Wrześniowski, op. cit., s. 54.

${ }^{36}$ Informacje o A. Parczewskim podaję za: S. Maksymowicz, Parczewski Alfons Józef Ignacy, [w:] Słownik pracowników książki polskiej, Warszawa-Lódź 1972, s. 659-660; K. Pol, Alfons Parczewski, „Rzeczpospolita” 1999, nr 36, s. 15; E. Andrysiak, Alfons Parczewski-życie i twórczość. Bibliografia, Kalisz 1992; eadem, Alfons Józef Ignacy Parczewski (1849-1933), prawnik, działacz spoleczny i polityczny, profesor Uniwersytetu Warszawskiego oraz Uniwersytetu Stefana Batorego $w$ Wilnie, „Biuletyn Szadkowski” 2006, t. 6, s. 7-42. 
na Wydziale Prawa Szkoły Głównej w Warszawie, którą ukończył w 1869 r. Po odbyciu aplikacji w Warszawie w 1872 r. przeniósł się do Kalisza i tutaj prowadził praktykę adwokacką aż do 1914 r. Jednocześnie poświęcał się działalności społecznej i naukowej. $Z$ jego inicjatywy powstało w tym mieście szereg instytucji dobroczynnych, kredytowych i kulturalnych. Od 1905 r. uaktywnił się w sferze polityki jako działacz narodowy. Był posłem do wszystkich czterech Dum Państwowych z ziemi kaliskiej i pracował w różnych komisjach tego ciała ustawodawczego. W latach pierwszej wojny przebywał w Warszawie i tutaj m.in. został powołany do komisji, której zadaniem było przygotowanie przyszłej konstytucji i ordynacji wyborczej.

Przez cały okres kaliski i warszawski prowadził aktywną działalność naukową nie tylko w swojej dyscyplinie, czyli prawie, ale także pisał prace historyczne, z zakresu historii literatury, etnografii. W 1915 r. rozpoczęła się jego akademicka kariera naukowa. Został organizatorem i dziekanem Wydziału Prawa na reaktywowanym za zgodą władz niemieckich Uniwersytecie Warszawskim. Za swoje zasługi dla tej uczelni otrzymał godność profesora honorowego tej uczelni. Jego zawodowe związki z Uniwersytetem Warszawskim zakończyły się w 1919 r. Po zakończeniu Wielkiej Wojny podjął aktywną działalność na rzecz przywrócenia uniwersytetu w Wilnie. W czerwcu 1919 r. przeniósł się do Wilna, gdzie został organizatorem i pierwszym dziekanem Wydziału Prawa Uniwersytetu im. Stefana Batorego. W latach 1922-1924 pełnił zaszczytną godność rektora USB ${ }^{37}$. W 1929 r. społeczność akademicka nadała mu godność doktora honoris causa tego Uniwersytetu. Był również członkiem Polskiej Akademii Umiejętności. W 1930 r. przeszedł na emeryturę, pozostając w Wilnie. Tam też zmarł 21 kwietnia 1933 r. Ciało jego przewieziono jednak do Kalisza i pochowano na miejscowym cmentarzu.

Od momentu odzyskania przez Polskę niepodległości zmieniły się diametralnie warunki rozwoju nauki polskiej. Powstały nowe polskie uczelnie, które, aby szybko rozwijać się, natychmiast potrzebowały wykształconych nowych kadr naukowych. Uczelnie warszawskie nie miały z tym większych problemów, gdyż zaproszenie władz przyjęło wielu znanych uczonych ze szkół galicyjskich. Nieco więcej kłopotów miały uczelnie w Wilnie i Poznaniu, a także prywatne, tutaj Wolna Wszechnica Polska i Wyższa Szkoła Handlowa (od 1933 r. Szkoła Główna Handlowa). Znani i cenieni naukowcy niezbyt chętnie decydowali się na opuszczenie prestiżowych uczelni w Krakowie i Lwowie, aby przenieść się do Wilna i Poznania. Należało sięgnąć po osoby wykształcone i z doświadczeniem zawodowym, funkcjonujące poza uczelniami oraz wykształcić swoich wychowanków, którzy z czasem mieli wzmocnić potencjał naukowy tych ośrodków. Dla młodych ludzi z dworów ziemiańskich otwierała się więc szansa na realizację

${ }^{37}$ Rektor Alfons Parczewski. Życie i prace. Odbitka z „Rocznika Prawniczego Wileńskiego” za rok 1930, Wilno 1930, s. 1-19. 
swoich aspiracji. Tym bardziej, iż zmieniła się optyka spojrzenia na stratyfikację społeczną w odrodzonej i demokratycznej Rzeczypospolitej. Ważną rolę w tym względzie odegrały decyzje i akty władz państwowych oraz postanowienia konstytucji marcowej z $1921 \mathrm{r}$. znoszące tytuły arystokratyczne i herbowe (art. 96) ${ }^{38}$. Dozwalano przy tym używania tytułów naukowych, które stawały się więc istotnym wyróżnikiem w społeczeństwie Drugiej Rzeczypospolitej.

Nie jestem w stanie podać dokładnych danych liczbowych, jaki odsetek stanowili profesorowie, już nie wspomnę o docentach i pomocniczych siłach naukowych, pochodzenia ziemiańskiego na polskich uczelniach w okresie międzywojennym. Wymagałoby to długotrwałych i żmudnych kwerend, a wyniki najpewniej wcale nie byłyby do końca zadowalające ${ }^{39}$. Tytułem przykładu w roku 1922/1923 w państwowych szkołach akademickich Drugiej Rzeczypospolitej zatrudniano ogółem 690 profesorów (624 zwyczajnych i 66 nadzwyczajnych), a w roku akademickim 1928/1929 było 802 profesorów (536 zwyczajnych i 741 nadzwyczajnych), w kolejnych latach stan ten w zasadzie niewiele się zmieniał. Na tym tle można dokładniej prześledzić interesujące mnie zjawisko poprzez ściślejsze dane dotyczące środowiska profesorów matematyków. Należy przy tym podkreślić, iż nie była to dyscyplina naukowa ciesząca się wielkim zainteresowaniem wśród przedstawicieli środowiska ziemiańskiego. Pomimo to, spośród 42 matematyków i logików, którzy w dwudziestoleciu międzywojennym zajmowali katedry profesorskie (przynajmniej przez pewien okres) lub wykładali jako profesorowie honorowi (jeden) lub tytularni (dwóch) na uczelniach państwowych i prywatnych, sześciu profesorów miało pochodzenie ziemiańskie. Jedynie wywodzących się ze środowiska nauczycielskiego było tylu samo, ale należy podkreślić, że ich ojcowie, w co najmniej pięciu przypadkach, posiadali herb szlachecki. Pięciu profesorów miało ojców lekarzy, z których dwóch było $\mathrm{z}$ doktoratem. Jedynie w przypadku trzech profesorów matematyków i logików można wskazać pochodzenie $\mathrm{z}$ tzw. warstw niższych, po jednym z rodziny rzemieślniczej, robotniczej i chłopskiej ${ }^{40}$.

Profesorowie matematycy i logicy wywodzący się ze środowiska ziemiańskiego w latach Drugiej Rzeczypospolitej stanowili więc 14\% w skali całej

${ }^{38}$ Art. 96 mówił, co następuje: Wszyscy obywatele sa równi wobec prawa. [...] Rzeczpospolita Polska nie uznaje przywilejów rodowych ani stanowych, jak również żadnych herbów, tytułów rodowych $i$ innych $z$ wyjątkiem naukowych, urzędowych $i$ zawodowych. Obywatelowi Rzeczypospolitej nie wolno przyjmować bez zezwolenia Prezydenta Rzeczypospolitej tytułów ani orderów cudzoziemskich.

${ }^{39}$ Nad kilkutomowym słownikiem uczonych polskich uniwersytetów w okresie międzywojennym w ramach przyznanego grantu NPRH od dwóch lat pracuje prof. Małgorzata Przeniosło z Uniwersytetu Jana Kochanowskiego w Kielcach.

${ }^{40}$ M. Przeniosło, op. cit., s. 321. Ojcowie pozostałych profesorów reprezentowali profesje głównie inteligenckie: urzędnicy, pracownicy służb mundurowych, inżynierowie, sędziowie, adwokaci, dziennikarze, a ponadto kupcy, przedsiębiorcy. 
42-osobowej grupy. Podkreślam jeszcze raz, iż ta dyscyplina nauki nie należała do najchętniej wybieranych do studiowania przez młodych ziemian, a niemal sporadycznie przez młode ziemianki. Stąd taki odsetek profesorów matematyków o ziemiańskich korzeniach należy uznać za wysoki. Wszyscy oni byli mężczyznami, tak jak i całe środowisko polskich matematyków - profesorów wyższych polskich uczelni w tym czasie.

Kilka tylko istotnych uwag kim byli profesorowie matematycy wywodzący się ze środowiska ziemiańskiego.

Profesor Józef Puzyna, jak w nekrologu wspomniano Józef kniaź z Kozielska Puzyna, był synem Włodzimierza i Felicji z Rudzkich, a wnukiem Andrzeja Puzyny, szambelana Stanisława Augusta Poniatowskiego i oficera gwardii Księstwa Warszawskiego. Przyszły znakomity matematyk urodził się 19 marca 1856 r. w Nowym Martynowie w pow. rohatyńskim ${ }^{41}$. W 1877 r. podjął studia na Wydz. Filozoficznym Uniwersytetu we Lwowie, które z przerwą na służbę wojskową ukończył w $1880 \mathrm{r}$. Trzy lata później uzyskał stopień doktora i wyjechał do Berlina na studia uzupełniające. Pod koniec 1884 r. złożył rozprawę na Uniwersytecie Lwowskim, która stała się podstawą do uzyskania habilitacji. W 1889 r. został tam profesorem nadzwyczajnym, a trzy lata później otrzymał profesurę zwyczajną i objął Katedrę Matematyki. W tej uczelni pełnił szereg godności - dziekana Wydz. Filozoficznego (1894/1895), rektora UL (1904/1905) i w kolejnym roku akademickim prorektora. W 1900 r. został członkiem korespondentem Akademii Umiejętności. Ponadto w 1917 r. był inicjatorem założenia we Lwowie Polskiego Towarzystwa Matematycznego. Naukowo zajmował się głównie teorią funkcji analitycznych. Uznawany jest za prekursora międzywojennej polskiej szkoły matematycznej.

Równolegle, obok pracy naukowej, wzorowo prowadził odziedziczony majątek ziemski Stańków w pow. stryjskim. Pod koniec XIX w. majątek miał rozległość ponad 1700 mórg, w tym ponad połowę obszaru zajmował las ${ }^{42}$. Kiedy część tego majątku sprzedał, jak określono „w ręce żydowskie”, w październiku 1918 r. sprawa została nagłośniona przez prasę, a profesor, a raczej właściciel ziemski został napiętnowany. Władze uczelni postanowiły pozbawić katedry bardzo zasłużonego profesora Puzynę i wysłać go na emeryturę ${ }^{43}$. Zapewne wydarzenie to wpłynęło na pogorszenie jego stanu zdrowia, a dodatkowo zniszczenie w wyniku działań wojennych nowo wystawionego dworu, spowodowało, iż 63-letni Józef Puzyna rozchorował się i zmarł 30 marca 1919 r. w Stańkowie, gdzie też został pochowany ${ }^{44}$.

\footnotetext{
${ }^{41}$ S. M. Brzozowski, Puzyna Józef (1856-1919), [w:] PSB, t. 29, Wrocław 1986, s. 494-495.

${ }^{42}$ Stańków, [w:] Stownik geograficzny Królestwa Polskiego..., t. 11, s. 211.

${ }^{43}$ K. Twardowski, Dzienniki, oprac. R. Jadczak, cz. 1, Toruń 1997, s. 62, 64, 106, 140.

44 „Czas”, nr 110, 28 IV 1919, s. 3; S.M. Brzozowski, op. cit., s. 495.
} 
Profesor Kazimierz Żórawski (Żorawski) był synem Juliusza Bronisława Żórawskiego herbu Trąby. Jego ojciec był przez lata dzierżawcą, administratorem majątków ziemskich, w końcu właścicielem dóbr mających rozległość kilkunastu tysięcy mórg, jednocześnie współzarządzał cukrownią „Krasiniec”, mając przy tym w niej udziały. Kazimierz Żórawski wywodził się więc z zamożnej rodziny ziemiańskiej. To postać ciekawa również ze względu na jego związki z Marią Skłodowską. Miłość obojga nie zakończyła się na ślubnym kobiercu, gdyż ojciec przyszłego profesora, a wówczas studenta, nie wyraził zgody na małżeństwo, uznając je za mezalians. Studiujący na Cesarskim Uniwersytecie Warszawskim syn, zależny finansowo od rodziców, nie potrafił im się przeciwstawić. Może dzięki temu rozstaniu Maria Skłodowska-Curie została podwójną noblistką, a Kazimierz uznanym polskim matematykiem. Kazimierz Żorawski urodził się 22 czerwca 1866 r. w Szczurzynie koło Ciechanowa. Po ukończeniu warszawskiego gimnazjum, w latach 1884-1888 studiował matematykę i fizykę na Cesarskim Uniwersytecie Warszawskim. Uzyskał stopień kandydata w zakresie nauk fizyko-matematycznych za pracę o astronomii. Kolejne lata spędził w Lipsku i Getyndze, studiując matematykę na tamtejszych uniwersytetach. W 1891 r. uzyskał stopień doktora w Lipsku. W tym też roku uzyskał habilitację w Szkole Politechnicznej we Lwowie, którą przeniósł dwa lata później na Uniwersytet Jagielloński. Tutaj w 1895 r. został profesorem nadzwyczajnym (objął II Katedrę Matematyki), a w 1898 r. otrzymał profesurę zwyczajną i objął I Katedrę Matematyki. Pełnił różne godności na uczelni: dziekan (1905/1906), rektor (1917/1918) i w następnym roku prorektor. Od 1900 r. był członkiem korespondentem Akademii Umiejętności, a w 1916 r. został wybrany członkiem czynnym AU. Po odzyskaniu niepodległości, w 1919 r. przeniósł się do Warszawy, gdzie otrzymał I Katedrę Matematyki na Politechnice, a w 1926 r. objął III Katedrę Matematyki na Uniwersytecie Warszawskim. Po przejściu na emeryturę w 1935 r. został mianowany profesorem honorowym tegoż Uniwersytetu. Zmarł 23 stycznia 1953 r. w Warszawie. Naukowo zajmował się teorią form różniczkowych, równaniami różniczkowymi, geometrią różniczkową i kinematyką ${ }^{45}$.

Inni profesorowie matematyki pochodzenia ziemiańskiego to:

Antoni Marian Łomnicki (17 stycznia 1881 r. Lwów - 3 na 4 lipca 1941 r., rozstrzelany przez Niemców we Lwowie - Wzgórza Wuleckie wraz z grupą innych lwowskich profesorów). Syn przyrodnika Alojzego i Marii ze Szczuckich. Cała jego praca naukowa związana była z uczelniami lwowskimi ${ }^{46}$.

Juliusz Rudnicki (30 marca 1881 Siekierzyńce koło Kamieńca Podolskiego - 26 lutego 1948 Toruń). Syn ziemianina Bohdana i Joanny Luizy z Lemmo-

${ }^{45}$ M. Przeniosło, op. cit.; Kazimierz Żorawski, https://www.impan.pl/Great/Zorawski/Zorawski-pl.html [dostęp: 12.12.2018 r.].

46 W. Orlicz, Łomnicki Antoni (1881-1941), [w:] PSB, t. 18, Wrocław 1973, s. 388-389. 
nierów, absolwent Sorbony w zakresie analizy matematycznej (1909). Kolejne szczeble kariery naukowej osiągał na różnych uczelniach: UJ (doktorat - $1911 \mathrm{r}$. i habilitacja - 1921 r.), profesor nadzwyczajny (II Katedra Matematyki na Wydz. Mechanicznym Politechniki Warszawskiej-1921 r.), profesor zwyczajny (II Katedra Matematyki na USB w Wilnie) ${ }^{47}$.

Jan Sleszyński (Śleszyński) (23 lipca 1854 r. Łysianka w gub. kijowskiej - 9 marca 1931 r. Kraków). Syn ziemianina Władysława Doliwa-Sleszyńskiego. Absolwent Uniwersytetu w Odessie: 1875 r. - stopień kandydata nauk w zakresie nauk matematycznych i magister - 1880 r. Studia uzupełniające odbył w Berlinie (1880-1882). Po powrocie zatrudniony na Uniwersytecie w Odessie (1893 r. - stopień doktora i profesor nadzwyczajny, 1898 r. - profesor zwyczajny). W 1911 r. przeniósł się do Krakowa i na UJ pracował jako docent, a od 1919 r. jako profesor zwyczajny matematyki i logiki (kierował II Katedrą Matematyki). W 1921 r. został członkiem korespondentem PAU, a po przejściu na emeryturę w 1924 r. otrzymał godność profesora honorowego $\mathrm{UJ}^{48}$.

Eustachy Karol Żyliński (1 października 1889 r. Kuna koło Bracławia gub. podolska - 4 lipca 1954 r. Łódź). Syn ziemianina Janusza Karłowicz Żylińskiego i Kazimiery ze Żmudzińskich. Studia na Uniwersytecie Kijowskim ukończył w 1911 r. Odbył studia uzupełniające w Getyndze, Cambridge i Marburgu (1912-1913). Po zakończeniu Wielkiej Wojny przeniósł się do Lwowa i na tutejszym uniwersytecie jako profesor nadzwyczajny objął I Katedrę Matematyki. W 1922 r. został mianowany profesorem zwyczajnym ${ }^{49}$.

W innych dyscyplinach, szczególnie należących do nauk humanistycznych, społecznych i medycznych, ten odsetek kadry naukowej wywodzącej się ze środowiska ziemiańskiego był z pewnością jeszcze wyższy niż w przypadku matematyków.

Kariery naukowe zapoczątkowane w przededniu Wielkiej Wojny albo tuż po odzyskaniu niepodległości kontynuowane były do wybuchu II wojny światowej albo już w powojennych uczelniach Polski Ludowej i PRL. W ankietach z tych czasów naukowcy wywodzący się ze środowiska ziemiańskiego skrupulatnie starali się ukrywać swoje pochodzenie społeczne. Znakomicie wskazuje na ten fakt analiza wypełnianych przez nich ankiet personalnych. Najczęściej wpisywali w rubryce pochodzenie - inteligencja pracująca. Tytułem przykładu chciałbym wskazać na takich profesorów związanych po wojnie z powołanym do życia w 1945 r. Uniwersytetem Łódzkim jak: Anna Chrząszczewska z domu Micha-

${ }^{47}$ L. Królikowski, Rudnicki Juliusz (1881-1948), [w:] PSB, t. 32, Kraków-Wrocław 1989-1991, s. $634-635$.

48 J.J. Jadacki, Sleszyński Jan (1854-1931), [w:] PSB, t. 38, Warszawa-Kraków 1997-1998, s. $563-565$.

${ }^{49}$ L. Maligranda, Eustachy Żyliński (1889-1954), https://www.diva-portal.org/smash/get/diva2: 994146/FULLTEXT01.pdf [dostęp: 10.12.2018 r.]. 
lecka, po adopcji Włastelica), Andrzej Feliks Grabski, Wacław Kirkor, Zofia Libiszowska z domu Gołuchowska, Maria Lipska-Librachowa, Mikołaj Łaźniewski, Stefania Skwarczyńska z domu Strzelbicka, Aniela Wasilewska-Kowalska (majątek Chruścinek pod Kutnem), Feliks Joachim Wiśniewski (Łazina koło Piątku $)^{50}$. W ankiecie osobowej z 1945 r. Anna Chrząszczewska wpisała pochodzenie - inteligencja pracująca, a zawód ojca - dyrektor gospodarstwa rolnego ${ }^{51}$. To „gospodarstwo rolne” to majątek ziemski Drozdnie, położony w powiecie kowelskim na Wołyniu należący do rodziny. Podobnie jak na UŁ wyglądała sytuacja w innych łódzkich uczelniach - Politechnice Łódzkiej, a szczególnie w Akademii Medycznej ${ }^{52}$.

Jedną z najbardziej ciekawych postaci pochodzenia ziemiańskiego wśród profesorów UŁ była Anna Chrząszczewska z domu Michalecka (następnie Włastelica). Urodziła się 16 października 1892 r. w majątku ojca Drozdnie, położonym w pow. kowelskim na Wołyniu. Po śmierci ojca Józefa Michaleckiego została adoptowana przez drugiego męża matki, obywatela ziemskiego Antoniego Włastelica $^{53}$. Jak inne panienki z zamożnych dworów pierwsze nauki pobierała w domu. Następnie została wysłana do szkoły średniej - Gimnazjum św. Katarzyny w Kijowie - którą ukończyła w 1908 r. Kolejnym etapem jej edukacji w latach 1908-1913 stały się Wyższe Kursy Żeńskie prowadzone na Fakultecie Fizyczno-Matematycznym Cesarskiego Uniwersytetu św. Włodzimierza w Kijowie. 17 października 1913 r. po złożeniu przewidzianych egzaminów

uznana została za godna dyplomu pierwszej kategorii z wszystkimi prawami i przywilejami, zadawanymi przez dyplomy odpowiednich męskich zakładów naukowych z wyjątkiem praw stużbowych $i$ stanowych ${ }^{54}$.

Dyplom dawał jej tytuł kandydata nauk przyrodniczych (doktorat).

Już w trakcie studiów w latach 1911-1912 pracowała jako młodszy asystent na Wyższych Kursach Żeńskich. Natomiast po uzyskaniu dyplomu, od 1913 r., rozpoczęła się jej znakomita kariera naukowa. Początkowo została starszą asystentką w Katedrze Chemii Organicznej kijowskiego Uniwersytetu, w której

${ }^{50}$ Archiwum Uniwersytetu Łódzkiego [dalej: AUŁ], Akta osobowe pracowników UŁ; J. Kita, Luminarze nauki polskiej w Uniwersytecie Łódzkim. Pro memoria, Łódź 2015.

${ }_{51}$ AUŁ, Akta osobowe Anny Chrząszczewskiej, sygn. 3443.

52 Por. A. Kurnatowski, Profesorowie i docenci wydziatów medycznych Uniwersytetu Łódzkiego i Akademii Medycznej. 1945-1964, Łódź, 2003; idem, Profesorowie i docenci Akademii Medycznej w Lodzi. 1965-1994, Łódź 2004; J. Kita, S. Pytlas, Profesorowie Uniwersytetu Łódzkiego w latach 1945-1994. Pro memoria, Łódź 1995; haec, W stużbie nauki. Profesorowie Uniwersytetu Łódzkiego w latach 1945-2004. Pro memoria, Łódź 2005.

${ }^{53}$ Józef Michalecki zmarł w 1899 lub 1900 r. Matka Julia z Oczosalskich w 1902 r. ponownie wyszła za mąż. 27 VI 1902 r. Anna Michalecka została adoptowana przez ojczyma i otrzymała nazwisko Włastelica.

${ }^{54}$ AUŁ, Akta osobowe Anny Chrząszczewskiej, sygn. 3443. 
pracowała do 1921 r. W 1914 r. w „Żurnale Russkago Chimiczeskago Obszczestwa" została ogłoszona drukiem jej praca kandydacka. Podczas okresu kijowskiego w jej życiu zaszły również poważne zmiany osobiste, a mianowicie 27 czerwca 1915 r. poślubiła Józefa Chrząszczewskiego, a dokładnie cztery lata później urodziła córkę Irenę $e^{55}$.

Wydarzenia polityczne związane z wojną polsko-sowiecką zmusiły ją do przeniesienia się w 1921 r. do Warszawy, gdzie jej kariera naukowa została przyspieszona. Związała się z Wolną Wszechnicą Polską, w której wykładała najpierw jako starszy asystent i adiunkt (1921-1925), następnie po przedstawieniu rozprawy habilitacyjnej, jako docent (1925) i wreszcie od 1926 lub 1927 r. jako profesor tytularny. Przed wybuchem II wojny światowej wykładała również w oddziale łódzkim WWP ${ }^{56}$. Jednocześnie z wykładami w WWP Anna Chrząszczewska w latach 1922-1939 zatrudniona była w Wojskowym Instytucie Przeciwgazowym w Warszawie oraz współpracowała z przemysłem farmaceutycznym. Jej badania zaowocowały kilkoma patentami oraz szeregiem innych sukcesów badawczych, które ze względu na wagę dla obronności państwa zostały utajnione i znalazły miejsce w sejfach Instytutu.

Po wkroczeniu wojsk niemieckich do Warszawy wyjechała w rodzinne strony i w latach 1939-1941 pracowała jako docent w Lwowskim Instytucie Politechnicznym w Katedrze Chemii Nieorganicznej i Analitycznej. W opinii prof. E.E. Sucharda z tegoż Instytutu możemy wyczytać, iż A. Chrząszczewska należy do dzielnych i sumiennych pracowników naukowych o wysokich kwalifikacjach. Charakteryzuje ją wielka pracowitość i duży entuzjazm zarówno do pracy naukowej jak i pedagogicznej. Zaznacza się umiejętnością jasnego wykładu i nieprzeciętnymi zdolnościami organizacyjnymi w zakresie nauczania ${ }^{57}$. Okres lwowski jej kariery zakończył się wraz z wkroczeniem wojsk niemieckich do miasta. A. Chrząszczewska ponownie wraz córką przybyła do Warszawy i tutaj pracowała dla przemysłu chemicznego i farmaceutycznego. Jednocześnie przygotowywała materiały wybuchowe dla struktur podziemnych Armii Krajowej. Do działalności konspiracyjnej nie będzie przyznawała się przez kilka powojennych dziesięcioleci ${ }^{58}$.

Swoje powojenne losy A. Chrząszczewska związała z Łodzią, do której przyjechała w marcu 1945 r. na wieść o tworzącym się w tym mieście uniwersytecie

${ }^{55}$ Ibidem. Mąż, Józef Chrząszczewski, pochodzenia szlacheckiego, był absolwentem Cesarskiego Uniwersytetu św. Włodzimierza w Kijowie. W 1915 r. niedługo po ślubie zmarła jej matka.

${ }_{56}$ AUŁ, Akta osobowe Anny Chrząszczewskiej, sygn. 3443; K. Baranowski, Oddziat Wolnej Wszechnicy Polskiej w Łodzi 1928-1939, Warszawa-Lódź 1977, s. 71.

${ }^{57}$ AUŁ, Akta osobowe Anny Chrząszczewsiej, sygn. 3443. Opinia prof. E.E. Sucharda z 25 II $1941 \mathrm{r}$.

${ }^{58}$ D. Klemantowicz, W. Ziomek, Wołyńskie korzenie profesorów Uniwersytetu Łódzkiego - prof. Anna Chrzaszczewska, „Ucrainica Polonica” 2004, t. 1, s. 377. 
i zajęła się organizacją Katedry Chemii Organicznej i w ogóle nauk chemicznych ${ }^{59}$. Tak jak ukrywała swoją działalność konspiracyjną, tak równie skrupulatnie skrywała swoje ziemiańskie korzenie. W ankiecie osobowej z 1945 r. wpisała pochodzenie - inteligencja pracująca, a zawód ojca - dyrektor gospodarstwa rolnego. To „gospodarstwo rolne” to znacznej wielkości majątek ziemski należący do rodziny. Może dzięki tym tajemnicom, 26 czerwca 1946 r. dekretem KRN podpisanym przez Bolesława Bieruta została mianowana profesorem zwyczajnym chemii organicznej. Zorganizowaną przez siebie Katedrą kierowała przez kilkanaście lat do 1963 r. kiedy odeszła na emeryturę.

Prof. Anna z Michaleckich/Własteliców Chrząszczewska była nie tylko wielkim autorytetem w uprawianej dyscyplinie naukowej, ale jednocześnie osobą serdeczną, lubianą przez współpracowników i studentów. Powszechnie nazywana była „Babcią" za swoją opiekuńczość wobec studentów i „siwiuteńkie włosy” pomimo wcale nieleciwego wieku ${ }^{60}$. Pochodząca z dużego majątku ziemiańskiego na Wołyniu prof. A. Chrząszczewska zmarła w wieku 96 lat w robotniczej Łodzi 21 kwietnia $1988 \mathrm{r}$.

Podobnie wyglądała droga na uniwersytecką katedrę również kilku innych profesorów powojennego Uniwersytetu Łódzkiego wywodzących się ze środowiska ziemiańskiego. Część z nich przez lata ukrywała swoje pochodzenie.

\section{BIBLIOGRAFIA}

\section{Źródła:}

Archiwum Uniwersytetu Łódzkiego

Akta osobowe Anny Chrząszczewskiej, nr sygn. 3443.

Akta osobowe pracowników UŁ.

Małachowice, [w:] Słownik geograficzny Królestwa Polskiego i innych krajów słowiańskich, t. 6.

Skarbek F., Pamiętniki Fryderyka hrabiego Skarbka, oprac. P. Mysłakowski, Warszawa 2009.

Stańków, [w:] Słownik geograficzny Królestwa Polskiego i innych krajów słowiańskich, t. 11.

Twardowski K., Dzienniki, oprac. R. Jadczak, cz. 1, Toruń 1997.

\section{Prasa:}

„Biesiada Literacka”, 1897, nr 11.

„Czas”, nr 110, 28 IV 1919.

„Kłosy” 1878, nr 702; 1890, nr 1282.

„Kurier Warszawski”, nr 168, 20 VI 1910; nr 169, 21 VI 1910.

Wrześniowski A., Władysław Taczanowski wspomnienie pośmiertne, „Tygodnik Ilustrowany” 1890, nr 4. „Zdrowie” 1902, R. 18, z. 5; 1903, R. 19, z. 4.

${ }^{59}$ J. Kita, S. Pytlas, W stużbie nauki. Profesorowie..., s. 20.

${ }^{60} \mathrm{Z}$ wywiadu prof. Romualda Skowrońskiego, ucznia prof. A. Chrząszczewskiej i rektora UŁ. Podaję za: D. Klemantowicz, W. Ziomek, op. cit., s. 377. 


\section{Opracowania:}

Andrysiak E., Alfons Józef Ignacy Parczewski (1849-1933), prawnik, działacz społeczny i polityczny, profesor Uniwersytetu Warszawskiego oraz Uniwersytetu Stefana Batorego w Wilnie, „Biuletyn Szadkowski” 2006, t. 6.

Andrysiak E., Alfons Parczewski-życie i twórczość. Bibliografia, Kalisz 1992.

Baranowski K., Oddział Wolnej Wszechnicy Polskiej w Lodzi 1928-1939, Warszawa-Lódź 1977.

Bieliński J., Królewski Uniwersytet Warszawski, t. 2, Warszawa 1911.

Bosiacki A., Adam Białecki, [w:] Profesorowie Wydziału Prawa i Administracji Uniwersytetu Warszawskiego 1808-2008, praca zbiorowa pod red. G. Bałtruszajtys, Warszawa 2008.

Broszkowska I., Fudakowscy herbu Dołega. Gałaź uherska, „Wiadomości Ziemiańskie” 2006, nr 26.

Brzozowski S.M., Puzyna Józef (1856-1919), [w:] Polski Słownik Biograficzny, t. 29, Wrocław 1986.

Cywińska A., Nalewajska L., Mistrzowie i przewodnicy. Profesorowie Warszawskiej Szkoły Głównej (1862-1869), Warszawa 2012.

Czepulis-Rastenis R., „Klassa umystowa”. Inteligencja polska Królestwa Polskiego 1832-1862, Warszawa 1973.

Dzieje inteligencji polskiej do roku 1918 r., pod red. J. Jedlickiego, t. 1: M. Janowski, Narodziny inteligencji 1750-1831, Warszawa 2008.

Epsztein T., Edukacja dzieci i młodzieży w polskich rodzinach ziemiańskich na Wołyniu, Podolu $i$ Ukrainie w II połowie XIX wieku, Warszawa 1998.

Halbersztadt J., Kobiety w murach Uniwersytetu Warszawskiego 1915-1939, [w:] Kobieta i kultura. Kobiety wśród twórców kultury intelektualnej $i$ artystycznej $w$ dobie rozbiorów $i$ wiepodleglym państwie, pod red. A. Żarnowskiej i A. Szwarca, Warszawa 1996.

Ihnatowicz I., Uniwersytet Warszawski w latach 1869-1899, [w:] Dzieje Uniwersytetu Warszawskiego 1807-1915, red. S. Kieniewicz, Warszawa 1981.

Jadacki J.J., Sleszyński Jan (1854-1931), [w:] Polski Słownik Biograficzny, t. 38, Warszawa-Kraków 1997-1998.

Kazimierz Żorawski, https://www.impan.pl/Great/Zorawski/Zorawski-pl.html [dostęp: 12.12.2018 r.].

Kiepurska H., Uniwersytet Warszawski w latach 1899-1915, [w:] Dzieje Uniwersytetu Warszawskiego 1807-1915, red. S. Kieniewicz, Warszawa 1981.

Kierzek A., Julian Kosiński (1833-1914) - chirurg szczególnie zastużony dla rozwoju otorynolaryngologii. Jego dokonania w leczeniu chorób krtani, „Otolaryngologia Polska” 2008, nr 2.

Kierzek A., Julian Kosiński (1833-1914) - chirurg szczególnie zastużony dla rozwoju otorynolaryngologii. Jego dokonania w leczeniu chorób uszu, nosa, gardła i pogranicza, „Otolaryngologia Polska” 2008, nr 2.

Kita J., Luminarze nauki polskiej w Uniwersytecie Łódzkim. Pro memoria, Łódź 2015.

Kita J., Ziemian Królestwa Polskiego obraz własny, „Studia z Historii Społeczno-Gospodarczej XIX i XX wieku" 2003, t. 1.

Kita J., Идеальный польский помещчик в представлении вариавских позитивистов, [w:] Модернизация в иентральной и восточной Европе. Идеи, програмы, реализачия, от. ред. Г.Ф. Матвеев, Мосгорархив, Мосkва 2000, s. 25-34.

Kita J., Pytlas S., Profesorowie Uniwersytetu Łódzkiego w latach 1945-1994. Pro memoria, Łódź 1995.

Kita J., Pytlas S., W stużbie nauki. Profesorowie Uniwersytetu Lódzkiego w latach 1945-2004. Pro memoria, Łódź 2005.

Klemantowicz D., Ziomek W., Wotyńskie korzenie profesorów Uniwersytetu Eódzkiego - prof. Anna Chrzązczewska, „Ucrainica Polonica” 2004, t. 1.

Kolbuszewska J., Kobiety w nauce - akademicki awans polskich historyczek wczoraj i dziś, „Sensus Historiae” 2015 , t. 19 , nr 2.

Kondracka M., Kobiety na uniwersytetach, [w:] Równe prawa i nierówne szanse. Kobiety w Polsce międzywojennej, pod red. A. Żarnowskiej i A. Szwarca, Warszawa 2000.

Królikowski L., Rudnicki Juliusz (1881-1948), [w:] Polski Słownik Biograficzny, t. 32, Kraków-Wrocław 1989-1991. 
Kurnatowski A., Profesorowie i docenci Akademii Medycznej w Łodzi. 1965-1994, Łódź 2004.

Kurnatowski A., Profesorowie i docenci wydziatów medycznych Uniwersytetu Łódzkiego i Akademii Medycznej.1945-1964, Łódź, 2003.

Litwin J., Holewiński Władysław Eustachy (1834-1919), [w:] Polski Stownik Biograficzny, t. 9, Kraków-Wrocław 1960-1961.

Łoś P.Sz., Szkice do portretu ziemian polskich XX wieku, Warszawa 2005.

Maksymowicz S., Parczewski Alfons Józef Ignacy, [w:] Słownik pracowników ksiązki polskiej, WarszawaŁódź 1972.

Maligranda L., Eustachy Żyliński (1889-1954), https://www.diva-portal.org/smash/get/diva2:994146/FULL TEXT01.pdf [dostęp: 10.12.2018 r.].

Manteufflowa M., Fudakowski Herman Bolestaw (1834-1878), [w:] Polski Stownik Biograficzny, t. 7, Kraków-Wrocław 1948-1958.

Mazurczak D., Kariery akademickie kobiet w Polsce międzywojennej - Uniwersytet Poznański, [w:] Kobieta $i$ kultura. Kobiety wśród twórców kultury intelektualnej i artystycznej $w$ dobie rozbiorów $i$ w niepodleglym państwie, pod red. A. Żarnowskiej i A. Szwarca, Warszawa 1996.

Molik W., Polskie peregrynacje uniwersyteckie do Niemiec 1871-1914, Poznań 1989.

Moraczewski A., Babczyński Tytus (1830-1910), [w:] Polski Stownik Biograficzny, t. 1, Kraków 1935.

Moraczewski A., Białecki Antoni Władystaw Emiljan, [w:] Polski Stownik Biograficzny, t. 2, Kraków 1936.

Mycielski M., Uniwersytet Królewski 1816-1831, [w:] Dzieje Uniwersytetu Warszawskiego 1816-1915, red. T. Kizwalter, Warszawa 2016.

Orlicz W., Łomnicki Antoni (1881-1941), [w:] Polski Stownik Biograficzny, t. 18, Wrocław 1973.

Perkowska U., Kariery naukowe kobiet na Uniwersytecie Jagiellońskim w latach 1904-1939, [w:] Kobieta $i$ kultura. Kobiety wśród twórców kultury intelektualnej i artystycznej $w$ dobie rozbiorów $i$ w niepodleglym państwie, pod red. A. Żarnowskiej i A. Szwarca, Warszawa 1996.

Perkowska U., Kształtowanie się zespołu naukowego w Uniwersytecie Jagiellońskim (1860-1920), Wrocław 1975.

Perkowska U., Studentki Uniwersytetu Jagiellońskiego w latach 1894-1939. W stulecie immatrykulacji pierwszych studentek, Kraków 1994.

Pol K., Alfons Parczewski, „Rzeczpospolita” 1999, nr 36.

Polak-Pałkiewicz E., Czy inteligencja istnieje?, „Niedziela” 2006, nr 29.

Przeniosło M., Matematycy polscy w dwudziestoleciu międzywojennym. Studium historyczne, Kielce 2011.

Rektor Alfons Parczewski. Życie i prace. Odbitka z „Rocznika Prawniczego Wileńskiego” za rok 1930, Wilno 1930.

Rudnicki Sz., Ziemiaństwo polskie w XX wieku, Warszawa 1996.

Schiller J., Universitas rossica. Koncepcja rosyjskiego uniwersytetu 1863-1917, Warszawa 2008.

Sobociński W., Okolski Antoni Stanisław (1838-1897), [w:] Polski Stownik Biograficzny, t. 23, Wrocław 1978.

Sokół S., Kosiński Julian (1833-1914), [w:] Polski Słownik Biograficzny, t. 14, Kraków-Wrocław 1968-1969.

Ziemianie polscy XX wieku. Stownik biograficzny, t. 1-11, red. J. Leskiewiczowa, T. Epsztein, Warszawa 1992-2016.

Żarnowski J., Inteligencja, [w:] W. Mędrzecki, Sz. Rudnicki, J. Żarnowski, Spoleczeństwo polskie w XX wieku, Warszawa 2003, s. 74-78.

Żarnowski J., O inteligencji polskiej lat międzywojennych, Warszawa 1965. 


\section{Jarosław Kita}

\section{FROM THE MANOR COURT TO THE UNIVERSITY CATHEDRAL A CONTRIBUTION TO THE GENESIS OF THE POLISH INTELLIGENTSIA}

L andowners and intelligence are two layers of Polish society that had complemented each other and played an important role in maintaining of the Polishness in the era of partitions, and seriously contributed to regaining independence in 1918. An educated landowner, or an intellectual of landowner origin, it was often difficult to define belonging to a particular social layer. After the January Uprising, publicists were writing about gentry as "country intelligentsia", which had to play an important role in the modernization of the Polish countryside. In the light of the previous findings of historiography, it appears that indeed the landowning environment became one of the main groups of recruitment of the Polish intelligentsia in the second half of the $19^{\text {th }}$ and the first half of the $20^{\text {th }}$ century.

An analysis of the sources of various provenance shows that one of the most important intellectual professional groups, to which were getting first sons and then daughters from the landowners families, were scientists. The main research problem is the attempt to characterize people of science, who had abandoned the mansions and decided to pursue a career at universities in Cracow, Lviv and Warsaw, and after independence, also Poznań, Vilnius and Lublin. This issue will be discussed both in the broader context of collective fates as well as selected individual biographies of Polish scholars on landed genealogy. An important selection criterion will be their simultaneous involvement in various political and social ventures.

Keywords: landowners, the university cathedral, intelligentsia. 